\title{
PENGARUH TEMAN SEBAYA TERHADAP PERKEMBANGAN MOTIVASI BELAJAR SISWA DI SMP MUHAMMADIYAH 1 MALANG
}

\author{
Moh Salahuddin, Nurbani Yusuf, Budiono \\ FKIP Universitas Muhammadiyah Malang \\ Email : salahuddindena@gmail.com
}

\begin{abstract}
ABSTRAK
Penelitian ini bertujuan untuk mengetahuai pengaruh teman sebaya terhadap perkembangan motivasi belajar siswa kelas VIII A SMP Muhammadiyah 1 Malang. Penelitian ini termasuk penelitian ex-post facto dengan pendekatan kuantitatif. Populasi dalam penelitian ini adalah seluru kelas VIII di SMP Muhammadiyah 1 Malang dan sampelnya adalah siswa kelas VIII A dengan jumlah 33 orang. Teknik pengumpulan data dalam penelian ini menggunakan dokumentasi dan angket koesioner. Uji prasarat analisis menggunakan uji normalitas dan uji linearitas, uji hipotesis menggunakan uji korelasi Product moment. Hasil penelitian menunjukan terdapat hubungan positif dan signifikan antara pergaulan teman sebaya dengan motivasi belajar yang di tunjukan dari hasil rhitung yang dipeolah dengan bantuan SPSS sebeser 0,575, sedangkan rtabel dengan $\mathrm{N}=33$ pada taraf kesalahan $5 \%$ sebesar 0,344 , sehingga $\rho$ hitung $>\rho$ tabel $(0,575>0,344)$. Selanjutnya ditemukan bahwa mayoritas siswa memiliki skor pergaulan teman sebaya yang berada pada kategori sedang dengan presentase 66,7\% dan mayoritas siswa peda motivasi belajar juga termasuk dalam kategori sedang dengan presentase yaitu sebesar 75,8\%.
\end{abstract}

Kata Kunci : Pergaulan teman sebaya, Motivasi belajar, SMP Muhammadiyah 1 Malang.

\begin{abstract}
The purpose of this research is to know how the thepeers's influence toward development of students's learning motivation at VIII A Class SMP Muhammadiyah 1 Malang. The kind of this research used ex-post facto with quantitative research. The population is the whole VIII class at SMP Muhammadiyah 1 Malang and the sample is the students who is in Class VIII A with amount 33 people. The data collection in this research used documentation and questionnaire. Test prerequisite analysis using normality test and linearity test, hypothesis test using product moment correlation test. The result of this study showed that there was a positive and significant correlation between peer association with learning motivation which showed from the result of rhitung which if with the help of SPSS shift 0,575, while rtabel with $\mathrm{N}=33$ at $5 \%$ error level 0,344 , so $r$ hitung $>r$ tabel $(0,575>0.344)$. Furthermore it was found that the majority of students have peer social scores that are in the medium category with a percentage of $66.7 \%$ and the majority of students pedamotivasibelajr also included in the category of premises premisesdenga $75.8 \%$.
\end{abstract}

Keywords: Peers association, Learning motivation, SMP Muhammadiyah 1 Malang.

\section{PENDAHULUAN}

Berdasarkan upaya tujuan pembangunan nasional, peran pendidikan sangat menentukan. Pendidikan diselenggarakan melalui berbagai jalur, yaitu jalur pendidikan di sekolah (formal), pendidikan luar sekolah/lingkungan masyarakat (non formal), dan pendidikan di lingkungan keluarga (informal). Ketiga jalur pendidikan tersebut berfungsi untuk meneruskan nilai-nilai luhur bangsa kepada generasi muda dan untuk mencapai tujuan 
pendidikan nasional yang telah ditetapkan dalam suatu sistem pendidikan nasional (Sisdiknas). Untuk mencapai tujuan pendidikan nasional tersebut perlu adanya kegiatan yang sinergis disetiap penyelenggaraan pendidikan, baik itu di sekolah, luar sekolah maupun lingkungan masyarakat, dan lingkungan keluarga. Oleh karena itu, sudahn menjadi suatu keniscahyaan bahwa perbaikan suamberdaya manusia harus terus ditingkatkan.

Untuk memenuhi hal tersebut, pendidikan masih dipercaya sebagai media yang sangat ampuh karena memiliki peranan yang sangat penting dan strategis. Hal ini sesuai dengan amanat UU No 20 tahun 2003 tentang sistem pendidikan nasional pasal 3 yang berbunyi "pendidikan nasional berfungsi mengembangkan kemampuan dan membentuk watak serta peradaban bangsa, yang bertujuan untuk mengembangkan potensi peserta didik agar menjadi manusia yang beriman dan bertakwa kepada Tuhan yang Maha Esa, berakhlak mulia, sehat, berilmu, cakap, kreatif, mandiri, dan menjadi warga ngara yang demokratis dan bertanggung jawab”.

Pendidikan merupakan salah satu system penting yang dipercaya untuk menciptakan sumber daya manusia (SDM) yang berkualitas. Keberhasilan pendidikan tentunya tidak terlepas dari sejauh mana perkembangan siswa dalam proses pembelajaran. Untuk meningkatkan hasil belajar siswa membutuhkan adanya motivasi yang tinggi dalam kegiatan pembelajaran. Ada beberapa unsur penting yang berperan terhadap perkembangan motivasi belajar siswa. Adapun unsur-unsur tersebut adalah teman, guru, orang tua, alat dan metode pembelajaran, serta lingkungan pelajaran.
Lingkungan pelajaran merupakan salah satu faktor penting yang mempengaruhi tingkah laku siswa. Lingkungan belajar yang dimaksudkan adalah lingkungan keluarga, teman, guru dan masyarakat sekitar. Selain lingkungan keluarga, teman merupakan lingkungan sosial pertama remaja untuk belajar berinteraksi dengan orang lain. Pada dasarnya hubungan pertemanan remaja dengan teman sebaya cenderung lebih dekat ketimbang dengan keluaganya sendiri, hal ini dikarenakan remaja lebih banyak menghabiskan waktunya untuk kegiatan sekolah, kegiatan ekstrakurikuler, maupun kegiatan di luar sekolah bersama teman sebayanya. Adapun beberapa kegiatan di sekolah yang saya maksudkan disini yaitu merupan kegiatan belajar dan juga kegiatan ekstarkurikuler siswa yang meliputi, kegiatan menulis karia ilmiah, basket, futsal, music orchestra, pramuka, tapak suci, belajar mengaji, dan senam sehat.

Pada dasarnya kelompok teman sebaya merupakan sekelompok anak atau remaja yang memiliki usia atau tingkat kematangan yang cenderung hampir sama (Santrock, 2007). Ada berbagai jenis teman sebaya dengan berbagai tipe, anak atau remaja memiliki hubungan pertemanan karena didasari oleh kesamaan dalam berbagai aspek, misalkan hobi, tujuan, dan seringnya bertemu. Setiap teman sepermainan memiliki karakter yang berbeda-beda. Perbedaan karakter tersebebut dapat berpengaruh besar dalam berbagai hal, seperti pola pergaulan dalam lingkungun khususnya pada prestasi belajar siswa. Hal tersebut dapat berpengaruh positif maupun pengaruh negatif terhadap prestasi belajar siswa, tergantung diri sendiri dan bagaimana cara siswa melakukan pergaulan dengan teman sepermainannya. Pada masa remaja siswa cenderung

Moh Salahuddin, Nurbani Yusuf dan Budiono, Pengaruh Teman Sebaya Terhadap Perkembangan Motivasi Belajar Siswa di SMP Muhammadiyah 1 Malang 
mengikuti pergaulan yang dilakukan oleh teman sepermainannya. Jika siswa bergaul dengan teman sepermainan yang suka menggunakan narkoba, merokok, dan juga minum minuman keras, maka siswa akan cenderung mengikuti untuk melakukan hal yang sama dengan teman sepermainannya, dan hal seperti inilah yang harusnya di hindari dari pergaulan anak atau remaja pada jaman sekarang karena dapat berpengaruh besar terhadap prestasi belajar siswa. Meskipun tidak sepenuhnya remaja akan mengikuti untuk melakukan hal yang sama seperti yang dilakukan teman sepermainannya namun kita juga mengetahui bahwasanya pada masa remaja merupakan masa dimana mereka mencari jati diri mereka dan bisa dikatakan pada masa ini remaja memiliki pemikiran yang tidak stabil, baik dalam pemikiran maupun prinsip hidup. Pengaruh teman sebaya tidak hanya memunculkan pengaruh negatif saja namun ada pula pengaruh dari sisi positifnya juga, teman sebaya sangat mempengaruhi proses pembelajaran karena dapat meningkatkan kemampuan kognitif siswa yaitu sebagai sumber informasi, sebagai teman diskusi untuk menyelesaikan masalah dalam proses pembelajaran, sebagai teman untuk belajar kelompok, mengemukakan pendapat dan untuk meningkatkan kemampuan dalam penalara.

Kualitas pendidikan di Negara kita masih perlu di tingkatkan lagi dengan menggunakan cara yang efektif, dengan melibatkan aspek-aspek penting dalam pindidikan yang mempengaruhi perkembangan motivasi belajar siswa seperti yang di tuliskan di atas bahwasanya aspek-aspek penting tersebut yaitu teman, orang tua, guru, dan lingkungan belajar siswa. Peningkatan motivasi belajar siswa bukan hanya menjadi tanggung jawab guru saja akan tetapi juga melibatkan semua aspek yang dituliskan di atas yaitu teman, guru, orang tua dan lingkungan belajar yang baik. Dalam sebuah studi, dikemukakan bahwa relasi diantara kawan sebaya yang buruk di masa kanakkanak berkaitan dengan putus sekolah dan kenakalan di masa remaja (Roff, Sells, dan Golden, 1972) dalam (Santrock, 2007: 57). Dalam studi lainnya, relasi yang harmonis dengan kawan-kawan sebaya di masa remaja berkaitan denga kesehatan mental yang positif di usia paruh baya (Hightower, 1990) dalam (Santrock, 2007: 57). Artinya ketika siswa dengan teman sepermainanya bergaul di lingkungan bermain yang baik maka perkembangan psikis siswa akan mengarah pada perkembangan yang positif dan perkembangan motivasi belajar siswa juga akan meningkat sehingga siswa dapat tumbuh menjadi pribadi yang berguna bagi kehidupan Bangsa dan Negara di kemudian hari.

Berdasarkan latar belakang masalah yang telah diuraikan di atas, Maka permasalahan penelitian ini dapat dirumuskan sebagai berikut.

a) Bagaimana program-progam sekolah yang dapat mempengaruhi motivasi belajar siswa di SMP Muhammadiyah 1 Malang?

b) Bagaimanakah pengaruh teman sebaya terhadap motivasi belajar siswa di SMP Muhammadiyah 1 Malang?

\section{METODE}

Penelitian ini menggunakan pendekatan kuantitatif. Pendekatan kuantitatif adalah suatu pendekatan yang bersifat konkrit/ empisis, obyektif, terukur, rasional, dan sistematis. Metode ini disebut metode kuantitatif karena data penelitian yang digunakan berupa angka-angka dan analisis menggunakan statistik (Sugiyono, 2014: 
7). Artinya, sebagian besar dari data penelitian ini berbentuk angka. Penelitian tentang pengaruh teman sebaya terhadap perkembangan motivasi belajar siswa di SMP Muhammadiyah 1 Malang ini termasuk jenis metode penelitian kuantitatif kausal. Kuantitatif kausal adalah hubungan yang bersifat sebab akibat. Jadi penelitian ini menggunakan dua variabel yaitu variabel independen (variabel yang mempengaruhi) dan juga variabel dependen (variabel yang dipengaruhi).

Penelitian ini di laksanakan di SMP Muhammadiyah 1 Malang yang beralamat di Jalan. Brigjend Slamet Riadi No. 134, Oro-oro Dowo, Klojen, Kota Malang, Jawa Timur. Waktu penelitian dilaksanakan pada bulan maret sampai bulan april 2017 .

\section{HASIL DAN PEMBAHASAN}

Sampel dalam penelitian ini adalah 33 siswa kelas VIII A SMP Muhammadiyah 1 Malang tahun ajaran 2016/2017. Data hasil penelitan ini terdiri dari dua variabel yaitu variabel terikat $(\mathrm{Y})$ motivasi belajar dan variabel bebas (X) teman sebaya.

"Sebelum melakukan uji persyaratan dan melakukan pengujian terhadap hipotesis yang diajukan, hasil analisis deskriptif akan terlebih dahulu dipaparkan”. "Statistik deskriptif ini bermaksud untuk memberikan gambaran mengenai data yang diperoleh pada setiap variabel”. “Adapun data yang akan disajikan yaitu data mean, median, modus, standart deviasi, skor tertinggi, dan skor terrendah”. "Data juga ditampilkan dalam bentuk tabel distribusi frekuensi, kecenderungan data, dan diagramdiagram”. Berikut analisis deskriptif data setiap variabel.

\section{Pergaulan Teman Sebaya}

"Untuk memperoleh data pada variabel teman sebaya kita dapat menggunakan instrumen skala psikologi”. "Instrumen yang diisi oleh 33 siswa sebagai responden ini mempunyai 24 butir pertanyaan, setiap butir pertanyaan memiliki 4 pilihan jawaban yang dapat di pilih siswa". "Skor tertinggi yang dapat diraih pada setiap butir adalah 4 dan skor terendah adalah 1". Jadi, skor tertinggi yang didapatkan dari skala ini adalah $24 \mathrm{x}$ 4 = 96 dan skor terrendah adalah $24 \times 1=$ 24

\section{Teman Sebaya}

Tabel 1. Tabulasi Statistik Deskriptif Teman Sebaya

\begin{tabular}{cc}
\hline Deskriptif & TemanSebaya \\
\hline $\mathrm{N}$ & 33 \\
\hline Rata-rata & 62.39 \\
\hline Median & 61 \\
\hline Modus & 61 \\
\hline StandarDeviasi & 4.71 \\
\hline Minimum & 54 \\
\hline Maksimum & 71 \\
\hline
\end{tabular}

Data pergaulan teman sebaya pada siswa kelas VIII A SMP Muhammadiyah 1 Malang memiliki "mean atau rata-rata sebesar 62,39, median 61, modus 61, dan standar deviasi 4,71. Skor maksimum yang dapat di capai responden adalah 71, sedangkan skor terendah yaitu 54”. Distribusi frekuensi data pergaulan teman sebaya dapat dilihat pada tabel di bawah ini.

\section{Tabel 2. Distribusi Frekuensi Pergaulan Teman Sebaya}

\begin{tabular}{cccc}
\hline \multirow{2}{*}{ Interval } & \multirow{2}{*}{ Frekuensi } & Frekuensi & Persentase \\
\cline { 3 - 4 } & & (dalam \%) & Komulatif \\
\hline $69-71$ & 4 & 12.1 & 12.1 \\
\hline $66-68$ & 6 & 18.2 & 30.3 \\
\hline $63-65$ & 4 & 12.1 & 42.4 \\
\hline $60-62$ & 9 & 27.3 & 69.7 \\
\hline $57-59$ & 6 & 18.2 & 87.9 \\
\hline $54-56$ & 4 & 12.1 & 100.0 \\
\hline Jumlah & 33 & 100 & \\
\hline
\end{tabular}

Moh Salahuddin, Nurbani Yusuf dan Budiono, Pengaruh Teman Sebaya Terhadap Perkembangan Motivasi Belajar Siswa di SMP Muhammadiyah 1 Malang 
"Berdasarkan tabel diatas, dapat diketahui bahwa interval 60-62 merupakan interval yang memiliki frekuensi siswa terbanyak yaitu 9 siswa dengan persentase 27.3\%”. Sementara itu, interval yang memiliki frekuensi terendah adalah 69-71,
63-65, dan 54-46 dengan frekuensi siswa masing-masing 4 siswa dan persentase sebanyak $12.1 \%$. Gambaran tabel frekuensi di atas dapat dilihat pada diagram batang di bawah ini.

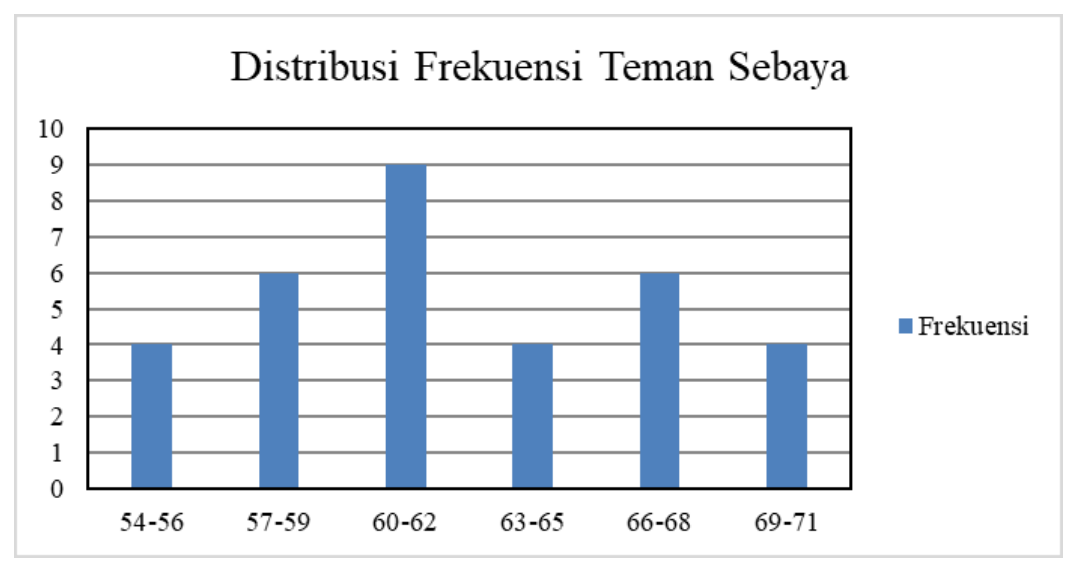

Gambar 1. Histogram Distribusi Pergaulan Teman Sebaya

"Selanjutnya data di atas digolongkan menjadi tiga kategori, yaitu kategori tinggi, sedang, dan rendah”. "Pengkategorian dimaksudkan untuk melihat kecenderungan distribusi frekuensi yang terjadi pada pengaruh teman sebaya”. Untuk lebih lengkapnya kita bisa lihat pada tabel berikut.

Tabel 3. Distribusi Kecenderungan Frekuensi Teman Sebaya

\begin{tabular}{cccc}
\hline Interval Skor & Kategori & Frekuensi & Persentase (\%) \\
\hline$>67$ & Tinggi & 6 & 18.2 \\
\hline $58-67$ & Sedang & 22 & 66.7 \\
\hline$<58$ & Rendah & 5 & 15.2 \\
\hline
\end{tabular}

Tabel 3. Menunjukkan "bahwa dengan persentase 66.7\%”. Untuk lebih pengaruh teman sebaya cenderung masuk lengkapnya kita bisa lihat pada diagram dalam kategori sedang sebanyak 22 siswa berikut.

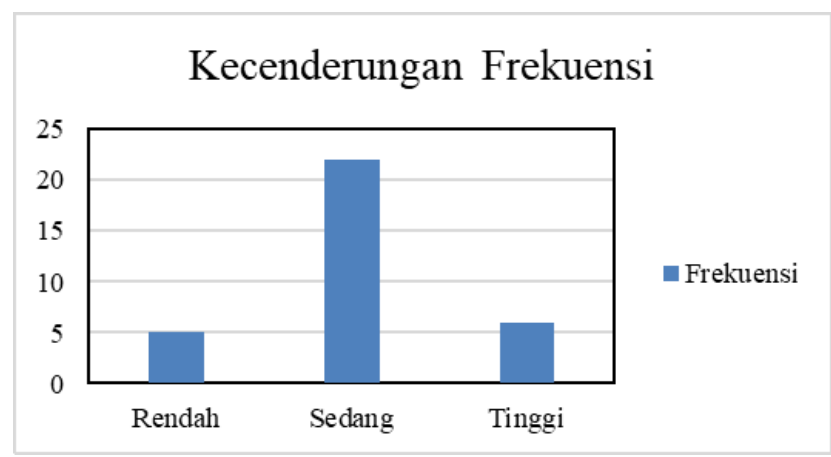

Gambar 2. Diagram Batang Kecenderungan Frekuensi Teman Sebaya.

Jurnal Civic Hukum Volume 3, Nomor 1, Mei 2018, hal. 52-61 


\section{Motivasi Belajar}

Data pada motivasi belajar "diperoleh melalui angket atau koesioner penelitian yang terdiri dari 18 butir pertanyaan dengan jumlah respoden 33 siswa kelas VIII A SMP Muhammadiyah 1 Malang”. "Setiap pertanyaan memiliki 4 pilihan jawaban yang dapat dipilih siswa, skor tertinggi yang dapat di raih pada setiap butir pertanyaan yaitu 4 dan skor terendah adalah 1". Jadi, skor tertinggi yang dapat diporoleh dari skala ini yaitu 18 x $4=72$ dan skor terrendah yaitu 18 x $1=18$.

\section{Motivasi Belajar}

Tabel 4. Tabulasi Statistik Deskriptif Motivasi Belajar.

\begin{tabular}{cc}
\hline Deskriptif & Motivasi Belajar \\
\hline $\mathrm{N}$ & 33 \\
\hline Rata-rata & 50.85 \\
\hline Median & 49 \\
\hline Modus & 48 \\
\hline StandarDeviasi & 4.79 \\
\hline Minimum & 42 \\
\hline Maksimum & 62 \\
\hline
\end{tabular}

Data motivasi belajar pada siswa kelas VIII A SMP Muhammadiyah 1 Malang memiliki mean atau rata-rata sebesar 50,58, median 49, modus 48, dan standar deviasi
4,79. Skor tertinggi yang dapat dicapai responden adalah 62, sedangkan skor terendah adalah 42. Untuk lebih lengkapnya dapat di lihat pada tabel di bawah.

Tabel 5. Distribusi Frekuensi Motivasi Belajar

\begin{tabular}{cccc}
\hline \multirow{2}{*}{ Interval } & \multirow{2}{*}{ Frekuensi } & Frekuensi & Persentase \\
\cline { 3 - 4 } & & $($ dalam \%) & Komulatif \\
\hline $61-64$ & 1 & 3.0 & 3.0 \\
\hline $57-60$ & 4 & 12.1 & 15.2 \\
\hline $53-56$ & 5 & 15.2 & 30.3 \\
\hline $49-52$ & 9 & 27.3 & 57.6 \\
\hline $45-48$ & 12 & 36.4 & 93.9 \\
\hline $41-44$ & 2 & 6.1 & 100.0 \\
\hline Jumlah & 33 & 100 & \\
\hline
\end{tabular}

"Berdasarkan tabel distribusi frekuensi di atas, dapat diketahui bahwa interval 45-48 merupakan interval yang memiliki frekuensi siswa terbanyak yaitu 12 siswa dengan persentase 36,4\%”. Sementara interval yang memiliki frekuensi terendah adalah 61-64 dengan frekuensi 1 siswa dan perentase sebanyak 3,0\%. Gambaran tabel frekuensi di atas dapat dilihat pada diagram batang di bawah ini.

Moh Salahuddin, Nurbani Yusuf dan Budiono, Pengaruh Teman Sebaya Terhadap Perkembangan Motivasi Belajar Siswa di SMP Muhammadiyah 1 Malang 


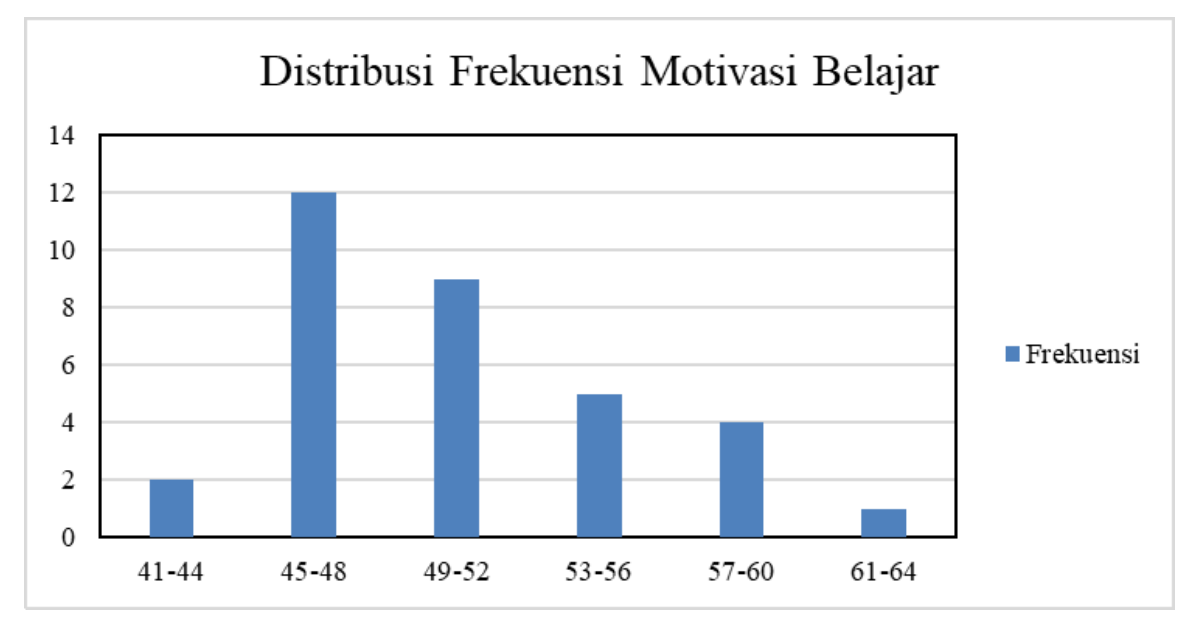

Gambar 3. Diagram Batang Distribusi Frekuensi Motivasi Belajar

"Selanjutnya data di atas digolongkan distribusi frekuensi yang terjadi pada menjadi tiga kategori, yaitu kategori tinggi, pengaruh motivasi belajar”. Untuk lebih sedang, dan rendah". "Pengkategorian lengkapnya kita bisa lihat pada tabel di dimasudkan untuk melihat kecenderungan bawah ini.

Tabel 6. Distribusi Kecenderungan Frekuensi Motivasi Belajar

\begin{tabular}{cccc}
\hline Interval Skor & Kategori & Frekuensi & Persentase (\%) \\
\hline$>56$ & Tinggi & 5 & 15.2 \\
\hline $46-56$ & Sedang & 25 & 75.8 \\
\hline$<46$ & Rendah & 3 & 9.1 \\
\hline
\end{tabular}

Tabel 6. Menunjukan bahwa motivasi persentase 75,8\%. Diagram batang berikut belajar cenderung masuk dalam kategori ini menunjukan tabel distribusi sedang sebanyak 25 siswa dengan kecenderungan frekuensi motivasi belajar.

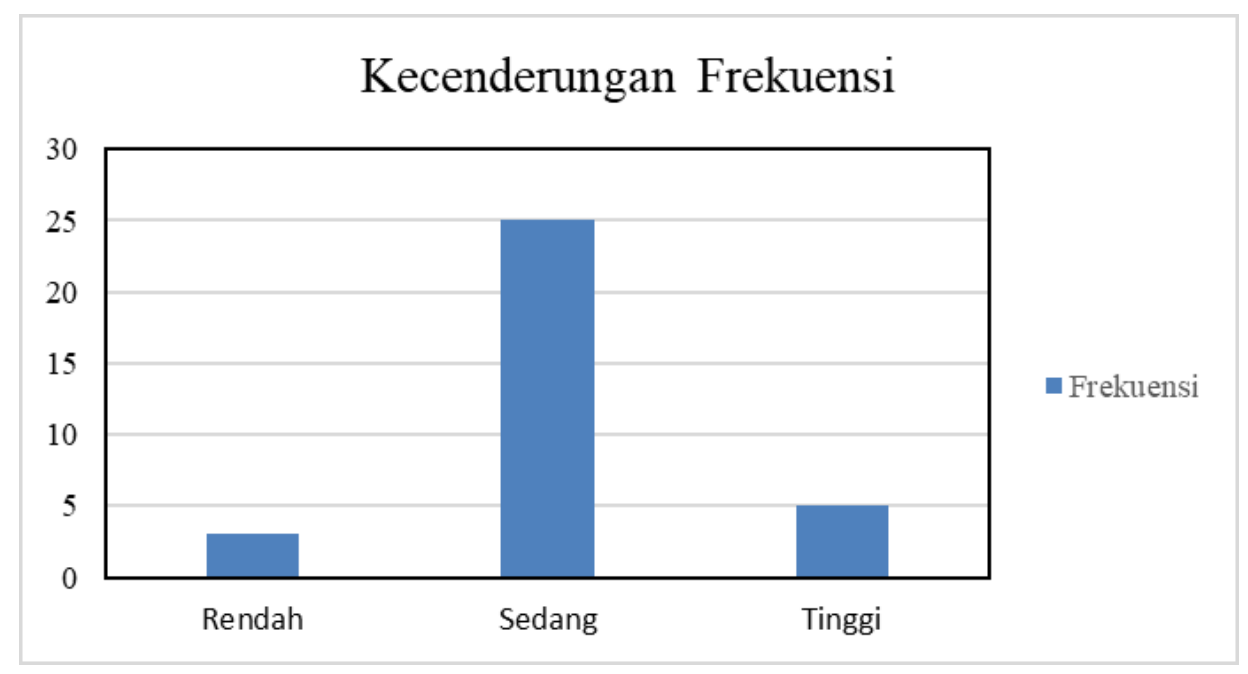

Gambar 4. Diagram Batang Kecenderungan Frekuensi Motivasi Belajar

Jurnal Civic Hukum Volume 3, Nomor 1, Mei 2018, hal. 52-61 


\section{Analisis Hasil Pembahasan.}

\section{Uji Normalitas}

Uji ini bertujuan "untuk mengetahui apakah data yang bersangkutan normal atau tidak". "Data yang mempunyai distribusi normal berarti data tersebut dikatakan benar-benar dapat mewakili populasi karena penelitian ini merupakan penelitian sampel". "Perhitungan normalitas data dalam penelitian ini menggunakan metode skewnes, yaitu dengan menghitung terlebih dahulu rario skewnes dengan rumus perhitungan skewnws/standar errorr of skewnes". "Jika rasio skewnes antara -2 sampai dengan 2 maka disrtibusi data normal (Prayitno, 2012:44)”.

"Setelah dilakukan perhitungan normalitas dengan bantuan softwere IMB statistik 20 di dapatkan hasil nilai rasio 0,55 untuk data pergaulan teman sebaya dan nilai rasio 1,23 untuk data motivasi belajar". Keduanya "berada pada interval -2 sampai dengan 2. Jadi, dapat di simpulkan bahwa data pergaulan teman sebaya dan motivasi belajar berdistribusi normal”.

\section{Uji Linearitas}

"Perhitungan linearitas digunakan untuk mengetahui apakah hubungan dua fariabel liner". "Hunbungan yang liner di tandai dengan adanya kenaikan skor pada suatu fariabel diikuti keanikan pula pada fariabel lainnya”. Jika di peroleh "nilai sig. Linierity $<0,5$ dan nilai sig. Deviation linierity $<0,5$ maka hubungan antara variabel adalah linier".

"Berdasarkan analisis yang di lakukan peneliti menggunakan softwere IMB SPSS statistik 20, di peroleh nilai yang sig”. "Linierity sebesar 0,001 , nilai yang di peroleh tersebut kurang dari 0,05, sedangkan nilai sig. Deviatio from linearity sebesar 0,652, lebih besar dari 0,05”. Maka, “dapat dikatakan bahwa hubungan antara variabel pergaulan teman sebaya dan motivasi belajar berjalan linear".

\section{Uji Hipotesis}

"Mengingat uji persyaratan analisis, yaitu uji normalitas dan linieritas telah dipenuhi, pengujian hipotesis di lakukan dengan munggunakan analisis korelasi produk moment person”. "Kriteria untuk menerima atau menolak hipotesis adalah dengan melihat perolehan harga $r$ atau di sebut juga rhitung gengan rtabel pada taraf signifikasi 5\%". "Bila rhitung ? rtabel maka Ho ditolak dan Ha diterima, Sebaliknya, apabila rhitung < rtabel Ho diterima dan Ha ditolak".

"Berdasarkan hasil analisis korelasi product moment person dengan bantuan softwere IMB SPSS statistik 20 diperoleh rhitung sebesar 0,575 nilai rtabel dengan jumlah $\mathrm{N}=33$ pada taraf kesalahan 5\% adalah 0,344”. "Secara ringkaas, korelasi antara variabel ditampilkan seperti tabel di bawah ini”.

Tabel 7. Hasil Analisis Korelasi Product Moment

\begin{tabular}{cc}
\hline rhitung & rtabel \\
\hline 0,575 & 0,344
\end{tabular}

"Dilihat dari perolehan harga $\mathrm{r}$ di atas, dapat diketahui bahwa 0,575 > 0,344 atau dengan kata lain rhitung < rtabel”. Maka dari itu, "dapat disimpulkan bahwa Ho ditolak dan Ha di rerima”. Jadi "terdapat hubungan yang positif dan signifikan antara pergaulan tenan sebaya dengan motivasi belajar kelas VIII A SMP Muhammadiyah 1 Malang”.

Tujuan dilakukan penelitian ini adalah "untuk mengetahui apakah terdapat hubungan yang positif antara pergaulan teman sebaya dengan motivasi belajar

Moh Salahuddin, Nurbani Yusuf dan Budiono, Pengaruh Teman Sebaya Terhadap Perkembangan Motivasi Belajar Siswa di SMP Muhammadiyah 1 Malang 
siswa kelas VIII A SMP Muhammadiyah 1 Malang tahun ajaran 2016/2017”. "Penelitian dengan ukuran sampel sejumlah 33 siswa ini menunjuka terdapat hubungan yang positif dan signifikan antara pergaulan teman sebaya dengan motivasi belajar siswa kelas VIII A SMP Muhammadiyah 1 Malang". "Hubunga yang positif dan signifikan ini diketahui dari besarnya harga rhitung yang lebih besar dari rtabel yaitu $0,575>0,344$ ". "Hubungan yang positif di sini berati bahwa kenaikan variabel $\mathrm{X}$, yaitu pergaulan teman sebaya akan diikuti pula oleh kenaikan variabel Y, yaitu variabel motivasi belajar, sebaliknya penurunan pergaulan teman sebaya akan diikuti pula oleh penurunan motivasi belajar". "Hal tersebut dapat dilihat bahwa pergaulan teman sebaya siswa yang berada pada kategori sedang yaitu 66,7\% diikuti pula dengan kecenderungan motivasi belajar siswa yang juga termasuk dalam kategori sedang yaitu 75,8". "Hubungan yang signifikan berarti bahwa hasil uji hipotesis digeneralisasikan ke populasi siswa kelas VIII A SMP Muhammadiyah 1 Malang”.

Melihat dari hasil penelitian di atas, dapat dilihat bahwa "semakin baik pergaulan teman sebaya seorang siswa, maka motivasi belajarnya akan semakin baik pula". "Hal ini tentu tidak bertentangan dengan pendapat Abu Ahmadi dan Widodo Supriyono (1991 : 131) yang menyatakan bahwa faktor yang memberikan andil pada prestasi belajar siswa adalah faktor yang berasal dari luar dan faktor yang berasal dari siswa". "Pergaulan, khususnya pergaulan dengan teman sebaya merupakan salah satu faktor penentu motivasi belajar yang berasal dari luar”.

Pergaulan harusnya berkualitas agar mampu menjadikan prestasi belajar optimal. "Kualitas tersebut dapat dilihat dari pihak yang terlibat saat bergau dengan siswa, kegiatan yang dilakukan, serta intensitasnya". Pergaulan teman sebaya siswa kelas VIII A SMP Muhammadiyah 1 Malang sendiri berada pada kategori sedang. Maka, "pergaulan sebaya yang berlangsung di SMP belum optimal dalam menjunjung budaya belajar". "Hal tersebut antara lain masih ditemuinya perilaku siswa yang kurang baik, seperti meremehkan nilai yang jelek, suka bersenda gurau saat pelajaran berlangsung, kurang selektif dalam memilih teman, melakukan kegiatan yang kurang bermanfaat, dan intensitas pergaulan yang kurang maksimal”.

\section{SIMPULAN}

"Hasil analisis data dan pembahasan pada bab sebelumya menunjukan bahwa nilai yang didapat dari rhitung adalah 0,575 , nilai rtabel dengan $\mathrm{N}=33$ pada taraf kesalahan $5 \%$ yaitu 0,344 , nilai rhitung > rtabel, maka Ho ditolak dan Ha diterima". Ha berbunyi bahwa "terdapat hubungan yang positif dan signifikan antara pergaulan teman sebaya dengan motivasi belajar siswa kelas VIII A SMP Muhammadiyah 1 Malang”. Jadi, dapat di simpulkan bahwa "terdapat hubungan positif dan signifikan antara pergaulan teman sebaya dengan motivasi belajar siswa kelas VIII A SMP Muhammadiyah 1 Malang”, dengan mayoritas berada pada kategori sedangdengan persentase teman sebaya yaitu $66,7 \%$ dan skor motivasi belajar siswa mayoritas juga berada pada kategori sedang pula, yaitu dengan persentase $75,8 \%$.

\section{DAFTAR PUSTAKA}

Ahmadi Abu dan Supriyono Widodo, (1991). Psikologi Belajar. Jakarta: Rineka Cipta. 
Alief , (2013). Uji linearitas dengan Tabel ANOVA SPSS.

Arikunto Suharsimi, (2010). Prosedur Penelitian Suatu Pendekatan Prektik. Jakarta: Rineka cipta.

B. Uno Hamzah, (2015). Teori Motivasi dan Pengukurannya: Analisis Di Bidang Pendidikan. Jakarta: Bumi Aksara.

Bungin, (2008). Metodelogi Penelitian Kuantitatif. Jakarta: Kencana Prenada Media Group.

Damsar, (2011). Pengantar Sosiologi Pendidikan. Jakarta: Kencana Pranada Media Group.

Dalyono. M, (2009). Psikologi Pendidikan. Jakarta: Rineka Cipta.

Desmita (2014). Psikologi Perkembangan Peserta Didik. Bandung: PT Remaja Rosdakarya.

Harlock, B Elizabeth,.(1997). Perkembangan Anak. Alih Bahasa. Med. Meitasari Tjandrasa dan Muslichah Zarkasih. Jakarta: Erlangga Indrawan Rulli dan Yuniawati Poppy, (2014). Metodelogi Penelitian Kuantitatif, Kualitatif, dan Campuran untuk Manajeman, Pembangunan, dan Pendidikan. Bandung: PT Refika Aditama.

Nurihsan Juntika, (2011). Dinamika Perkembangan Anak dan Remaja: Tinjauan Psikologi, Pendidikan, dan Bimbingan. Bandung: PT Refika Aditama.

Poerwanti Endang dan Widodo Nur, (2002). Perkembangan Peserta Didik. Malang: Universitas Muhammadiyah Malang.

Prayitno Duwi, (2012). Cara kilat Belajar Analisis Data dengan SPSS 20. Yogyakarta: Andi

Santrock John .W, (2007). Remaja, Jilid 2, Edisi ke 11. Alih Bahasa. PT Gelora Aksara Pratama.
Sardiman, (2011). Interaksi dan Motivasi Belajar Mengajar. Jakart: Raja Grafindo Persada.

Semiyawan Coni. M, (1998). Perkembangan Peserta Didik. Jakarta: Depdikbud.

Surya Hendra, (2010). Rahasia Membuat Anak Cerdas dan Manusia Unggul. Jakarta: Elex Media Komputindo

Sugiyono , (2014). Meode Penelitian Kuantitatif, kualitatif, dan $R \& D$, Bandung: Alfabeta

Sutirna, (2013). Perkembangan dan Pertumbuhan Peserta Didik. Yogyakarta: Andi Offset.

Vembrianto, (1993). Sosiologi Pendidikan. Jakarta: Grasindo.

Wicaksono Okky, Penelitian Tentang: Hubungan Antara Pergaulan Teman Sebaya dengan Prestasi Belajar Siswa Kelas 5 SD Gugus Jendran Sudirman, Kecamatan Sempor, Kabupaten Kebumen. Program Studi PGSD Universitas Negeri Yogyakarta Juli 2014.

Yusuf Syamsu, (2014). Psikologi Perkembangan Anak dan Remaja. Bandung: PT Remja Rosdakarya.

Yusuf Syamsu dan Sugandi Nani M, (2011). Perkembangan Peserta Didik. Jakarta: Raja Grafindo Persada.

UU No. 20 Tahun 2003 Tentang Sistim Pendidikan Nasional.

http://aliefworksop.com/2013/11/13/ujilinearitas-dengan-tabel-spss/ (diakses 12 Februwari 2017)

http://kbbp://.web.id/pengaruh di akses pada tanggal (10, januari 2017).

Moh Salahuddin, Nurbani Yusuf dan Budiono, Pengaruh Teman Sebaya Terhadap Perkembangan Motivasi Belajar Siswa di SMP Muhammadiyah 1 Malang 